\title{
Effects of Apple on Human Health
}

\author{
Said Efe Dost \\ Karamanoglu Mehmetbey University, Technical Sciences Vocational School, \\ Plant and Animal Production Department, Karaman, Turkey \\ E-mail: saidefe.dost@gmail.com
}

\begin{abstract}
Apple is a temperate climate fruit species and grown on many continents. Apple fruit is cheap, worldwide known and most consumed fruit kind. Apple's biochemical contents (Antioxidant and Phenolic) are important for human health. In our modern world due to stress and other various factors, our body is affected by free radicals every day. Antioxidants cling to these free radicals to protect the body from diseases (cancer, cardiovascular diseases, asthma) and eliminate the destructive effects of radicals. The consumption of an apple in our daily nutrition program is important for health and is recommended by experts.
\end{abstract}

Keywords: Apple (Malus X domesticaBorkh.), Antioxidant, Phenolic, Human Health

DOI: $10.7176 /$ JSTR/5-10-09

\section{Introduction}

The apple fruit which is cultivated in all continents except Antarctica in the world is seen in wide geography in the temperate climate zone and only in high altitudes in the tropics. Fruits of this kind can be directly consumed as raw, dried or canned, or processed in fruit juice, jam, marmalade or alcoholic beverages. Apart from its cultures in different parts of the world, the fruits of some otherMalusspecies can be used as raw or processed and for medicinal purposes while their plants are utilized as rootstocks. ManyMalusspecies and inter-species hybrids can also be used as ornamental plants (Luby 2003). Therefore, apple is one of the most important fruit species produced in the world and according to FAO's 2017 data, it is ranked second after bananas (113.92 million tons) with a production output of 83.14 million tons. China is the biggest apple producer with 41.4 million tons of production in the world. The USA is ranked second with 5.17 million tons, followed by Turkey with 3.03 million tons and Poland with 2.2 million tons of production (Anonymous 2017).

Among these species, M. Orientalis, whose gene center in North Anatolia, Caucasus, and northern Iran, formed new hybrids in North Anatolia on trade and migration routes with Malus species and hybrids of east and west, and thus, there occurred many gene transitions between species (Ercisli 2004; Volket al.2008). Hence, North Anatolia has a great contribution to the development of the cultivated apple. North Anatolia regarded as the top region regarding apple cultivation in Turkey in parallel with the spread of its wild subcultures has a chilly and damp climatic condition in coastal regions (Özbek 1978) and hosts a large number of local apple varieties which adapted to this ecology.

The increasing level of education and awareness leads to valuing healthy nutrition in daily diet. Fruit and vegetable consumption in our daily diet is important for a healthy life. Vegetables and fruits contain phenolic compounds in different qualities and amounts according to their regions of production and consumption. Wrong and insufficient nutrition due to our life conditions, stress, air and water pollution, smoking and alcohol consumption and fast foods constantly threaten our health and creates harmful free radicals in the human body (Eken 2007). Phenolic compounds and antioxidants capture these radicals and neutralize the oxidation. Apple fruit is an-all-seasons fruit and a durable, economical, delicious and widely consumed species. The studies conducted on apple have shown that the antioxidants and phytochemicals in apple and its pulp have positive effects on health. The apple has become a part of the human culture thanks to its widespread use since ancient times and its positive contribution to health (Küçükkömürler and Karakuş 2009).

Apple fruit is rich in phenolic compounds, pectin, sugar, macro and microelements (Kalinowska 2014). The amount of components varies depending on the type, harvest date, and storage conditions. The 
amount and type of these substances in apple are different in flesh and skin. Apple fruit contains antioxidant varieties such as quercetin, catechin, epicatechin, procyanidin, Coumaricacid, chlorogenic acid, gallic acid and fluorides (Bulantekin 2017). There is a strong correlation between the phenolic content of the apple and its antioxidant activity, and it has a great ability to "sweep" free radicals. Apple is a rich source of phytochemicals and its regular consumption reduces the risk of some cancer types, cardiovascular diseases, asthma and diabetes (Belitzand Grosch 1995).

This study aims to reveal apple's contribution to human health. In this context, after some information is given on the apple's cultivation history, its phenolic content, and the breeding works, the contribution of phenolic content on human health will be highlighted under the light of current literature.

\section{History of Apple Cultivation}

The history of apples dates back to human history or before that. Archaeological excavations show that cave people hid apple seeds and dried fruits under the soil (Gilbert 2001). Since humans progressed from hunting and gathering to agriculture in B.C 8000, sweet apple varieties spread to the world through trade and wars (Lynd 2008). The culture apple (Malus $\times$ domestica Borkh), which is an inter-species hybrid complex among Malus species, is an important fruit recognized worldwide. The earliest archaeological remains of the apple found in Anatolia in BC 6500 show that this species has been known by humans for thousands of years (Luby 2003). Central Asia is believed to be the center of domestication and diversity of apples (Gharghaniet al.2009). The wild apples of Turkestan (Kazakhstan, Kyrgyzstan, Uzbekistan, Turkmenistan, and Tajikistan) are considered to be relatives of current apples. The unified archaeological and molecular data prove that travelers carried wild apples in their saddlebags or unintentionally in horse intestines from China to the Danube River; from the Middle East to Europe before Neolithic age or Bronze age. Then, apple cultivation in Mesopotamia became widespread probably in 3800 years ago. This form of cultivation was transferred to the Romans, Persians, and Greeks; and the Greeks developed it worldwide 2000 years ago (Harris et al.2002).

Table 1. Apple's Placein Taxonomy (Ferree and Warrington 2003).

\begin{tabular}{ll}
\hline Team: & Rosales \\
\hline Family: & Rosaceae \\
\hline Sub-Family: & Pomoideae - Maloideae \\
\hline Genus: & Malus \\
\hline Type : & There are many species. \\
\hline Type name: & Spread area: \\
M. angustifolia & (East of the USA) \\
M. coronaria & (East of Canada and the USA) \\
$\begin{array}{l}\text { M. baccata } \\
\text { M. mandshurica }\end{array}$ & (Northeast China, Eastern Siberia, Mongolia, North India, \\
\hline M. prunifolia & (Central and northeast China, eastern Russia, Japan) \\
M. sieversii & (Central Asia) \\
M. orientalis & (Northeast Anatolia, Caucasus, Iran) \\
M. sylvestris & (Europe) \\
\hline
\end{tabular}

Apple trees were indispensable in orchards and home gardens in the 19th century in Europe, and they were also used to cover public roads and private areas in landscape designs. Trees have many purposes such as aesthetic and landscape design, and protection from sun and wind protection. There were a few thousand varieties used in the country for different purposes in this period. Also, different varieties were cultivated in different regions of Poland. The varieties in Western Poland were brought from western Europe. Local varieties that were characteristic to certain regions were also cultivated. Modern fruit cultivation caused major changes in the present varieties of apple trees in the second half of the twentieth century (Treurenand Anderson 2010).

In this world where demand for new and high-quality varieties is increasing on each passing day, researchers are trying to meet this need by making use of classical and modern breeding techniques, or by trying to attain possible quality candidates by evaluating the existing genetic diversity in the gene centers. Though morphological, molecular and historical findings reveal that the ancestor of culture apple 
is Malus sieversii (Ledeb.) type M. Roem. from Central Asia, M. orientalis and M. sylvestris (L.) along the historical silk road extending from Asia to western Europe also played important parts as participatory agents in breeding current apple species (Luby 2003; Volket al.2008; Cornilleet al.2012). Today, modern apple breeding has two important goals. The first is to increase the marketability, and second is to provide the species with features that will reduce production costs (Janicket al.1996). Apple is also a species on which intensive breeding work is conducted. It is observed that this kind of breeding work in the world is limited to the crossbreeding of well-known commercial varieties; that 'Red Delicious', 'Golden Delicious' and 'Jonathan' are often used as parents in many, modern species; and that tendency towards genetic uniformity increases even more as the mutant of famous varieties start appearing. Yet, the desired element in apple breeding works is a broader genetic diversity to develop new species that have high fruit quality, efficiency, and disease-resistant characteristics. Wild Malus species spread over a wide area in Asia, Asia Minor, Europe, and North America are important genetic resources in the development of apple varieties and/or rootstocks that are compatible with different environmental conditions (Hokansonet al.2001; Kumar et al.2010; Zhang et al.2012). Among these species, M. Orientalis, whose gene center in North Anatolia, Caucasus, and Northern Iran, formed new hybrids in North Anatolia withMalus species and hybrids of the east and west on trade and migration routes and thus, there were many gene transitions between species (Ercisli 2004, Volket al. 2008).

Breeding activities aim to minimize the negative characteristics of varieties and to provide the new and desired properties (fruit quality, yield, resistance to diseases, etc.). Thus, it will open the way for the development of varieties with good yields, no-periodicity, attractiveness, coloration, and resistance to diseases (Janicket al.1996). However, as the breeding activities destroy wild species belonging to the region and the replacement of these species by the new standard varieties, the extinction possibility of wild gene sources is increasing every day (Karlıdağand Eşitken 2006). They stated that the protection of wild genotypes is of great importance in recent years.

\section{The Phenolic Content of Apple}

Phytochemicals (phenolic compounds, flavonoids, carotenoids), which are abundant in many plant species, are called biologically active substances due to their positive effects on human health and play an important role in reducing the risks in many chronic diseases (Bulantekinand Kuşçu 2017). Since apple fruit has high antioxidant activity, it is quite effective in reducing lipid oxidation, reducing cholesterol and preventing cancer cell accumulation, and in preventing many diseases that pose major risks to human health (especially cancer, cardiovascular diseases, diabetes). Ninety percent of the energy in apple tissues is composed of simple carbohydrates, mainly sugars in which fructose is in dominant form. Fructose and sucrose content of an apple is lower than other fruits. The fiber content of the apple is approximately $3 \mathrm{~g} / 100 \mathrm{~g}$ in wet weight (FW) and consists mainly of pectin (Ferretti et al.2014). Apple has a large number of phenolic compounds and also has a total antioxidant capacity. The distribution of these phenolic compounds happens due to differences in tissues and varieties (Khanizadechet al.2008). It has all kinds of unique chemical properties. The emergence of phenolic compounds ensures the stimulating properties of flavor and health as well as the internal quality parameters of fruits which are the naturally occurring secondary metabolites (Lattanzio 2003). As bioactive compounds, phenolics play an important role in plant defense mechanisms and plant antioxidant expression. It is known that the phenolic composition of plant tissue can determine the sensitivity/tolerance level to fungal infections and pests (Useniket al.2004). The resistance of plants to fungal and bacterial diseases depends on the presence of phenolic compounds in their bodies and their speed and ability to produce them. The research found out that the varieties resistant to apple black stains are the ones with faster phenolics, chlorogenic, caffeic and ferulic acids accumulation rates in their bodies (Useniket al. 2004; Treutter 2005). The apples with more dense phenolic compounds are said to have higher antioxidant activities. The phenolic compounds in apple can be divided into several groups.

(A)Hydroxybenzoic Acids: P-hydroxybenzoic acid, Protocancic acid, Gallic acid, Syringic acid, Genetic acid,

(B)Hydroxycinnamic Acids and their derivatives: P-coumaric Acid, Caffeic Acid, Ferulic Acid, Chlorogenic Acid,

(C)Flavonols: Quercetin Glycoside forms,

(D)Dihydrocalacones: Phloridzin and its derivatives,

(E)Anthocyanidins: Cyanidins and Glycosides, 


\author{
(F)MonomericFlavonols: Epicatechin, Catechin, \\ (G)Oligomeric Flavonols: Procyanidins (Chai et al.2012).
}

Dihydrochalcones (phlorizin) associated with flavonoids are present in high amounts in the Rosaceae family. Many researchers have investigated the importance of this substance for human health. It is active in diabetics, metabolic syndrome and prolonging food shell life so much so that it is currently used in beverages, medicines and even cosmetics (Goschet al.2009). Lipid oxidation, especially the oxidation of unsaturated fatty acids, is an important issue in the food industry that affects food quality and consumers' health. The apple peel was investigated as a natural antioxidant source. It has been shown that apple peel extracts are effective inhibitors of the oxidation of unsaturated fatty acid in a model system and thus, can be considered as potential sources of natural nutrient antioxidants (Huber andRupasinghe 2009).

\title{
4. The Effect of Phenolic Substances on Diseases and Human Metabolism
}

A high diet of fruits and vegetables can reduce the risk of chronic diseases such as cardiovascular disease and cancer, and phytochemicals such as phenolics, flavonoids, and carotenoids in fruits and vegetables can play an important role in reducing the risk of chronic disease. Apple is a rich, widely consumed phytochemical source and in epidemiological studies, it was found out that the regular consumption of apples reduced the risk of certain cancers, cardiovascular diseases, asthma, and diabetes. Laboratory studies have found that the apple has a very strong antioxidant activity, inhibits cancer cell proliferation, reduces lipid oxidation and lowers cholesterol. Apple contains various phytochemicals all of which are potent antioxidants such as Quercetin, Catechin, Phloridzin, and Chlorogenic acid. Although the phytochemical composition of the apple varies considerably between different apple varieties, small changes in phytochemicals occur during the ripening of the fruit (BoyerandLiu 2004). Oxidants as byproducts of normal metabolism are harmful to DNA, protein, and lipids. They claimed that this damage (the same size as the radiation produced) had a significant share in degenerative diseases such as cancer, cardiovascular disease, immune system regression, brain dysfunction, and cataract. It contains ascorbate, tocopherol, and carotenoids as antioxidant defense mechanisms. Fruit and Vegetable Diet is a major source of ascorbate and carotenoids and a single source of tocopherol. Since only $9 \%$ of Americans consume five kinds of vegetable and fruit servings in their daily diet, their nutritional diet has improved and had a healthy life opportunity (Ameset al.1993). It is important that polyphenolics and antioxidants are absorbed into the body and consumed sufficiently to attain active levels in the body. It is also possible that these components are absorbed to some extent by the body (sufficient consumption); that is, it is meaningless to take a high amount (Hollman et al.1995; Olthof et al.2001).

Feskanichet al. (2000) found that apple consumption prevented cancer risk, especially lung cancer. Approximately 77000 women and 47000 men participated in the experiment. It was determined that lung cancer decreased by $21 \%$ in women with apple consumption while this effect was not fully observed in men. It is emphasized in the study that consumption of fruits and vegetables has an important role in reducing the risk of lung cancer, and especially apple consumption is more effective than other fruits and vegetables in reducing the risk of lung cancer. The risk of lung cancer in women who consume an apple or pear a day has been greatly reduced. In the study conducted by a women health organization, 40000 women were observed for 7 years. As a result of the study, they observed that Flavonoids present in apples reduced the risk of cardiovascular diseases by 35\% (Sessoet al.2003). Apple consumption helps the body to heal lung and asthma diseases and improves resistance to them, and diabetes also appears to be less common in people who consume apples. In epidemiological studies, some flavonoids have been associated with protection against aging skin diseases (Van der Sluis 2000). Apple and especially polyphenol consumption not only reduce the risk of cardiovascular disease, lung, and colorectal cancer but also reduce the risk of type II diabetes and helps to lose weight (Boyer and Liu 2004).In a study conducted with 1600 adults in Australia, they found that apple and pear consumption decreased the risk of asthma and positively affected lung health, but consumption of any fruits and vegetables did not produce the same effect (Woods et al. 2003). The consumption of mulberry and apple has been shown to have a major impact on reducing the risk of developing diabetes (Knektet al. 2002). The use of modified pectin has shown that it is possible to remove heavy metals from the blood (Eliazet al.2006). It is generally known that the compounds are more in the peel of the apple than in its flesh; so, their consumption with peel will be healthy and beneficial. In their study conducted with the apple with red peel color, Yuri et al. (2009) stated that the antioxidant activity in the peel is 4-15 times higher than the fruit flesh though it varies according to different types. 


\section{Result}

Apple fruit is cultivated in all continents (except Antarctica) due to its adaptation to many different climatic and soil conditions. Apple fruit is offered in large quantities and cheaply for people's consumption. Being cheap means that people from every social stratum has access to it. Everything in moderate amounts has a positive effect on our body and the body also has the power of absorbing them in certain amounts (Hollman et al.1995; Olthof et al.2001).

It has been emphasized in many studies that the phenolic components in apple have a great share in resistance to diseases and strengthening the body defense system in human metabolism.

Today, standard varieties of apple are widely consumed. However, the gardens established with standard varieties destroy the local varieties and damage the gene resources. In recent years, the breeding works in the world has supported growing new varieties by preserving local ones. Studies have shown that many local varieties are resistant to climatic conditions, diseases, and pests. Local varieties come to the fore in terms of fruit characteristics as well as their gene sources. Many local varieties contain higher amounts of phenolic and antioxidants than standard varieties (Hollman et al.1995; Olthof et al.2001). Indeed, in their study, Coşkun andAşkın (2016) found that the compound value of many local varieties was 2-4 times higher than the standard varieties.

Therefore, the use and consumption of local species in apple production/apple orchard establishments is recommended. Many local apple varieties are present in the form of a single tree on farmland or in the wild in the mountains since Turkey is located in the passageway of migrations. Since the trees do not have enough cultural care, they can not reveal their phenological and pomological characteristics. Attending to local varieties on suitable growing conditions with standard rootstocks is of great importance in revealing the potential of these varieties. Molecular biology and genetic evaluations can be made in genetic protection parcels and it can be explained whether the desired properties are present in local varieties. The obtained new local varieties can be used as parents in new kinds of breeding works. since local varieties are rich in their phenological, pomological and chemical properties, plants and fruits obtained from these species will appear as high demand products in the world market.

\section{References}

[1] Anonymous. 2017. Web Sitesi: http://www.fao.org/faostat/en/\#data/QC Erişim Tarihi: 02.05.2019.

[2] Ames, B. N., Shigenaga, M. K., and Hagen, T. M. 1993. Oxidants, antioxidants, and the degenerative diseases of aging. Proc. Natl. Acad. Sci. USA. 90; 7915-7922.

[3] Belitz, H. D., Grosch, W. 1995. Food Chemistry. Springer Verlag. Heidelberg, 992s.

[4] Boyer, J. and Liu, R. H. 2004. Apple phytochemicals and their health benefits. Nutrition Journal; Vol. 3; 1-15.

[5] Bulantekin, Ö. ve Kuşçu, A. 2017. Elmada Bulunan Fitokimyasallar ve Diğer Zengin Bileşenlerin İnsan Sağlığına Yararlar. Meyve Bilimi, 213-218, ISSN: 2148-0036

[6] Chai, L., Song Y-Q., Leung W.K. 2012.Genetic polymorphism studies in periodontitis and Fcreceptors. J Periodont Res; 47; 273-285.

[7] Cornille, A., Gladieux, P., Smulders, M. J. M., Roldan-Ruiz, I., Laurens, F., Cam, B., Nersesyan, A., Clavel, J., Olonova, M., Feugey, L., Gabrielyan, I., Zhang, X. A., Tenaillon, M. I. and Giraud, T. 2012. New insightin to the history of domesticated apple: secondary contribution of the European wild apple to the genome of cultivated varieties. PLoSGenet., 8(5); e1002703.

[8] Coşkun, S. ve Aşkın, M. A. 2016. Bazı Yerli Elma Çeşitlerinin Pomolojik ve Biyokimyasal Özelliklerinin Belirlenmesi, Süleyman Demirel Üniversitesi Ziraat Fakültesi Dergisi 11 (1); 120131. 
[9] Eken, S. 2007. Bazı Materyallerde Antioksidan Tayinleri. Yüksek Lisans Tezi. Yıldız Teknik Üniversitesi Fen Bilimleri Enstitüsü. İstanbul. 94s.

[10] Eliaz, I., Hotchkiss, A. T., Fishman, L. M., and Rode, D. 2006. The Effect of Modified Citrus Pectin on Urinary Excretion of Toxic Elements. Wiley Inter Science Vol. 20; 859-864.

[11] Ercisli, S. 2004. A short review of the fruit germplasm resources of Turkey. Genetic Resources and Crop Evolution, 51;419-435.

[12] Ferree, D. C., and Warrington, I. J. 2003. Apples, Botany, Production and Uses. CABI Publishing, pp. 2-6, Cambridge, USA.

[13] Ferretti, G., Turco, İ., Bacchetti, T. 2014. Apple as a Source of Dietary Phytonutrients: Bioavailability and Evidence of Protective Effects against Human Cardiovascular Disease. Food and Nutrition Sciences, 5; 1234-1246.

[14] Feskanich, D., Ziegler, R. G., Michaud, D. S., Giovannucci, E. L., Speizer, F. E., Willett, W. C., Colditz, G. A. 2000. Prospective study of fruit and vegetable consumption and risk of lung can ceramong men and women. J. NatlCancerInst. 92(22); 1812-1823.

[15] Gharghani, A., Zamani, Z., Talaie, A. R., Oraguzie, N. C., Fatahi, R., Hajnajari, H., Wiedow, C., Gardiner, S. E. 2009. Genetic identity and relation ships of Iranian apple (Malus 3 domestica Borkh.) cultivars and landraces, wild Malus species and representative old apple cultivars based on simple sequence repeat (SSR) marker analysis. Genet Resour Crop Evo 156; 829-842.

[16] Gilbert, A. 2001. All about Apples. Hyland House Publishing, Flemington, Australia.

[17] Gosch, C., Halbwirth, H., Kuhn, J., Miosic, S., Stich, K. 2009. Biosynthesis of phloridzin in apple (Malus domestica Borkh.). Plant Science 176 (2); 223-231.

[18] Harris, S. A., Robinson, J. P., Juniper, B. E. 2002. Genetic clues to the origin of the apple. Trends in Genetics, 18(8); 426-430.

[19] Hokanson, S. C., Lamboy, W. F., Szewc-McFadden, A. K. and McFerson, J. R. 2001. Microsatellite (SSR) variation in a collection of Malus (apple) species and hybrids. Euphytica, $118 ; 281-294$.

[20] Hollman, P. C. H. de Vries, J. van Leeuwen, S. D. Mengelers, M. J. B. Katan, M. B. 1995. Absorption of dietary quercetin glycosides and quercetin in healthy ileostomy volunteers. Am. J. Clin. Nutr., 62; 1276-1282.

[21] Huber, G. M., and Rupasinghe, H. P. V. 2009. Phenolic Profiles and Antioxidant Properties of Apple Skin Extracts. Journal Of Food Science; 74; 693-700.

[22] Janick, J., Cummins, J. N., Brown, S. K., Hemmat, M. 1996. Apples. In: Fruit Breeding, Vol. I, Tree and Tropical Fruits, Janick, J. and Moore, J.N. (eds.) John Wiley \& Sons, New York, pp. 177.

[23] Kalinowska, M., Bielawska, A., Lew and owska-Siwkiewicz, H., Priebe, W., Lew and owski, W. 2014. Apples: content of phenolic compounds vs. variety, part of apple and cultivation model, extraction of phenolic compounds, biological properties. Plant Physiology and Biochemistry, 84; $169-188$

[24] Karlıdağ, H. ve Eşitken, A. 2006. Yukarı Çoruh vadisinde yetiştirilen elma ve armut çeşitlerinin bazı pomolojik özelliklerinin belirlenmesi. Yüzüncü Yıl Üniversitesi Ziraat Fakültesi, Tarım Bilimleri Dergisi, 16(2); 93-96. 
[25] Khanizadeh, S., Tsao, R., Rekika, D., Yang, R., Charles, M. T., Rupasinghe, H. P. V. 2008. Polyphenol composition and total antioxidant capacity of selected apple genotypes for processing. Journal of Food Composition and Analysis; 21; 396-401.

[26] Knekt, P., Kumpulainen, J., Jarvinen, R., Rissanen, H., Heliovaara, M., Reunanen, A., Hakulinen, T., Aromaa, A. 2002. Flavonoid in take and risk of chronic diseases. American J. Clin. Nutr. 76(3); 560-568.

[27] Kumar, S., Volz, R. K., Alspach, P. A. ve Bus, V. G. M. 2010. Development of a recurrent apple breeding programme in New Zealand: a synthesis of results, and a proposedrevised breeding strategy. Euphytica, 173; 207-222.

[28] Küçükkömürler, S., Karakuş, S. Ş. 2009. Elma, Sağlık ve Kültür. Tarım Bilimleri Araştırma Dergisi 2 (1);183-186. Issn: 1308-3945.

[29] Lattanzio, V. 2003. Bioactive Polyphenols: Their Role in Quality and Storability of Fruit and Vegetables. J Appl Bot; 77; 128-146.

[30] Luby, J. J. 2003. taxonomic classification and brief history, In: Apples, Botany, Production and Uses. Ferree, D. C.,Warrington, I. J. (eds), CABI Publishing, 1-14, Cambridge.

[31] Lynd, M. 2008. Great moments in apple history. www.hort.purdue.edu.

[32] Olthof, M.R.,Hollman P.C. H., Katan, M.B. 2001. Chlorogenic acid and caffeic acid are absorbed in humans. J. Nutr. 131 (1); 66-71.

[33] Özbek, S. 1978. Özel Meyvecilik (Kışın Yaprağını Döken Meyve Türleri). Ankara Üniversitesi Basımevi, No: 128, 485 s., Ankara.

[34] Sesso, H. D., Gaziano, J. M., Liu, S., Buring, J. E. 2003. Flavonoid in take and the risk of cardiovascular disease in women. American J. Clin. Nutr. 77(6); 1400-1408.

[35] Treutter, D. 2005. Significance of flavanoids in plant resistance and enhancement of their biosynthesis. Plant Biology, 7; 581-591.

[36] Treuren, G., Anderson, K. 2010. The Employment Expectations of Different Age Cohorts: Is Generation Y Really that Different. Australian Journal of Career Development; Vol 2; 49-60.

[37] Usenik, V., Mikulic Petkovsek M., Solar A. and Stampar F. 2004. Flavanols of leaves in relation to apples cabresistance. Journal of Plant Diseases and Protection. 111; 137- 144.

[38] Van der Sluis, A. A., Dekker, M., Verkerk, R., Jongen, W. M. F. 2000. An improved, rapid in vitro method to measure antioxidant activity; application on selected flavonoids and apple juice. J. Agric. Food Chem. 48; 4116- 4122.

[39] Volk, G. M., Christopher, M. R., Reilley, A. A., Henk, A. D. and Reeves, P. A. 2008. Genetic diversity and disease resistance of wild Malus orientalis from Turkey and Southern Russia. J. Amer. Soc. Hort. Sci., 133(3); 383-389.

[40] Woods, R. K., Walters, E. H., Raven, J. M., Wolfe, R., Ireland, P. D., Thien, F. C., Abramson, M. J. 2003. Food and nutrient intakes and asthma risk in young adults. American J. Clin. Nutr. 78(3); 414-421. 
[41] Yuri, J. A., Neira, A., Quilodran, A., Motomura, Y. and Palomo, I. 2009. Antioxidant activity and total phenolics concentration in apple peel and flesh is determined by cultivar and agroclimatic growing regions in Chile. Journal of Food, Agriculture and Environment, 7(3-4); 513-517.

[42] Zhang, Q., Li, J., Zhao, Y., Korban, S. S. and Han, Y. 2012. Evaluation of genetic diversity in Chinese wild apples pecies along with apple cultivars using SSR markers. Plant Mol. Biol. Rep., 30; 539-546. 